\title{
The relationship between landscape configuration and plant species richness in forests is dependent on habitat preferences of species
}

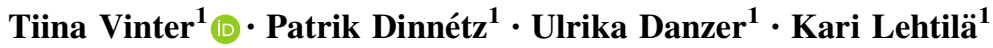

Received: 23 June 2016/Revised: 26 August 2016/Accepted: 29 August 2016/Published online: 17 September 2016

(C) The Author(s) 2016. This article is published with open access at Springerlink.com

\begin{abstract}
To assess the effects of landscape configuration on local plant species richness, we tested whether local species richness of forest understory plants is affected by the total forest area and forest edge length in the adjacent landscape. We also tested whether the landscape effect on species richness is different for forest and edge species. We estimated species richness from 113 forest sites in four regions in Northern Europe. At each site, we studied two plots, one at the edge and one in the core of the forest. Total forested area and forest edge length in circles with a $1-\mathrm{km}$ radius, together with plot-specific variables of environmental conditions and temporal continuity of forests, were recorded at each plot. The amount of forest and the length of the forest edge in the adjacent landscape had a significant positive effect on local species richness of all understory plant species. As expected, edge species were positively affected by increasing length of the forest edge in the landscape, but surprisingly there was no effect of forest area on species richness of forest species. Temporal forest continuity had a negative effect on species richness of edge species but no effect on species richness of forest species. Our results suggest that forest edge length had a stronger landscape effect on understory plant species richness than forest area. Implications of these findings for
\end{abstract}

Communicated by Claus Bässler.

Electronic supplementary material The online version of this article (doi:10.1007/s10342-016-0994-3) contains supplementary material, which is available to authorized users.

Tiina Vinter

tiina.vinter@sh.se

1 School of Natural Sciences, Technology and Environmental Studies, Södertörn University, 14189 Huddinge, Sweden the management of forest landscapes depend on priorities given to different species groups in biodiversity conservation, i.e. if emphasis is in total species richness or species richness of forest or edge species.

Keywords Landscape species pool - Spatial mass effect . Landscape configuration - Dispersal - Landscape heterogeneity $\cdot$ Edge effects

\section{Introduction}

The dynamics of biodiversity in ecosystems can be described through the loss of species due to local extinctions and replenishment through colonisations from a regional species pool (Hanski 1999; With and King 1999; Ouborg and Eriksson 2004; Ovaskainen and Hanski 2004). One of the most important drivers for both extinction and colonisation rates in natural habitats is landscape configuration (Tilman 2004). The well-known species-area relationship suggests that larger areas of a certain habitat type can support higher regional species richness (Lomolino 2000; Dengler 2009). The landscape species pool hypothesis adds that the size of the landscape-wide species pool influences local species richness: regionally high habitat availability results in a high regional species richness, which contributes with larger diversity of possible colonists locally (Tscharntke et al. 2012). The colonists from a species pool of a regionally abundant habitat may support extinction-prone, sparse local populations through the spatial mass effect (Shmida and Whittaker 1981). In forest habitats, these hypotheses predict that the forest area in a landscape can affect local species richness. Another important landscape character that also may affect species richness is the length of the forest edges (Fagan et al. 1999; 
Laurance et al. 2006). Habitat area and edge length describe different qualities of landscape configuration, but they are interrelated (Fletcher et al. 2007). At landscape level, the relationship between forest edge length and forest area is humped with maximum edge length in landscapes with intermediate forest cover (Fahrig 2003). When comparing landscapes with similar total forest area, longer forest edge indicates that forests have more irregular margins and/or that forest patches are smaller.

Species may respond differently to landscape configuration depending on their realised niche breadths, reproduction, dispersal abilities, and other life history traits (Ewers and Didham 2006; Lindborg et al. 2012). Vascular plant species with forest understory as their primary habitat are in this article referred to as forest species. Large forest area in a landscape can support large populations of forest species and provide high connectivity, which lowers extinction risks and enhances dispersal opportunities (Honnay et al. 1999; Fischer and Lindenmayer 2007). With increasing forest edge length in the landscape, when forest area remains constant, dispersal opportunities of the forest species should decrease, as edges form dispersal barriers. Increase in forest edge length may be caused by habitat fragmentation, which has been recognised to be a major cause in the decline of species richness (MacArthur and Wilson 1967; Fahrig 2003; Jamoneau et al. 2012; Lindborg et al. 2012). Edges may also be inferior habitats for the forest species. Hence, when the forest edge length in the landscape increases, species richness of the forest species is expected to decrease (Honnay et al. 2002a). On the other hand, forests also contain species that prefer edge habitats, referred to in this paper as edge species. Contrary to the forest species, the edge species are expected to be positively affected by the amount of forest edge in the surrounding landscape, but not necessarily by forest area (Brothers and Spingarn 1992; Fraver 1994; Fox et al. 1997; Honnay et al. 2002b; Godefroid and Koedam 2003). Therefore, local species richness of the specific species groups may be affected differently by landscape patterns, such as total forest area and forest edge length.

The anticipated effect of forest edge length in the landscape on total plant species richness at regional and local scale is not obvious. There are different possible effects of edge length on plant diversity, depending on the types of species that dominate the plant metacommunities (Leibold et al. 2004; Matthews et al. 2014). Forest edge length is expected to have a negative effect on the diversity of forest species, so species diversity should decline with increasing forest edge length in metacommunities dominated by forest species. In metacommunities that are dominated by edge species, we predict that forest edge length has a positive effect on species richness of the regional species pool due to the species-area relationship (Holt 2010; Hofmeister et al. 2013; Kolk and Naaf 2015).

The aim of this study was to examine how forest area and the length of the forest edge in the landscape affect local species richness of vascular plants in the understory of common forest habitats in northern Europe. We established a random sample of study sites in forests in four regions around the Baltic Sea. The sampling design contained two paired $625-\mathrm{m}^{2}$ study plots at each study site, one at the forest edge and one in the interior of the forest. This paired design allows us to analyse the landscape effects both at the forest edge and in the forest interior. We test the effect of landscape configuration on species richness both for forest species and edge species, but also for all species found in our study plots, including generalist matrix species. We address the following questions: (1) Does forest area in a landscape affect local species richness of forest species, edge species, and all understory plant species? (2) Does the length of the forest edge in a landscape affect local species richness of forest species, edge species, and all understory plant species? (3) Is local species richness of the forest species, edge species, and all species affected differently by forest area and forest edge length of the adjacent landscape? We also tested whether local environmental conditions and temporal forest continuity modified the landscape effect of forest area or edge length on different types of species.

\section{Methods}

\section{Study areas and design}

The four regions around the Baltic Sea that were selected for this study are the whole country of Estonia, the county of Södermanland in central Sweden, the county of Skåne in southern Sweden, and the state of Mecklenburg-Vorpommern in north-eastern Germany (Fig. 1). In all four regions, a major deforestation occurred several centuries ago due to fuel wood consumption and agricultural expansion, followed by reforestation predominantly with production forests, starting in the nineteenth century and accelerating during the twentieth century (Peterken 1996; Cousins et al. 2015). Estonia and Södermanland are located in the hemiboreal zone, whereas Skåne and north-eastern Germany are situated in the temperate zone (Esseen et al. 1997). Forest cover of total land area is $48 \%$ in Estonia (Põder 2014), $61 \%$ in Södermanland (Christiansen 2014), $36 \%$ in Skåne (Christiansen 2014), and $24 \%$ in Mecklenburg-Vorpommern (Thünen-Institut 2015). For the selection of forest sites, a large number of random geographical coordinates were generated for each region. The random coordinates were positioned on a digital land-use 
Fig. 1 a Study areas: Estonia, Södermanland in central Sweden, Skåne in southern Sweden, and MecklenburgVorpommern in northern Germany. b Illustration of the study design with random sampling of forest sites within each region, with Estonia as an example. c Selection of large core and edge plots $(25 \times 25 \mathrm{~m})$ and random distribution of small plots inside the large plots $(0.5 \times 0.5 \mathrm{~m})$

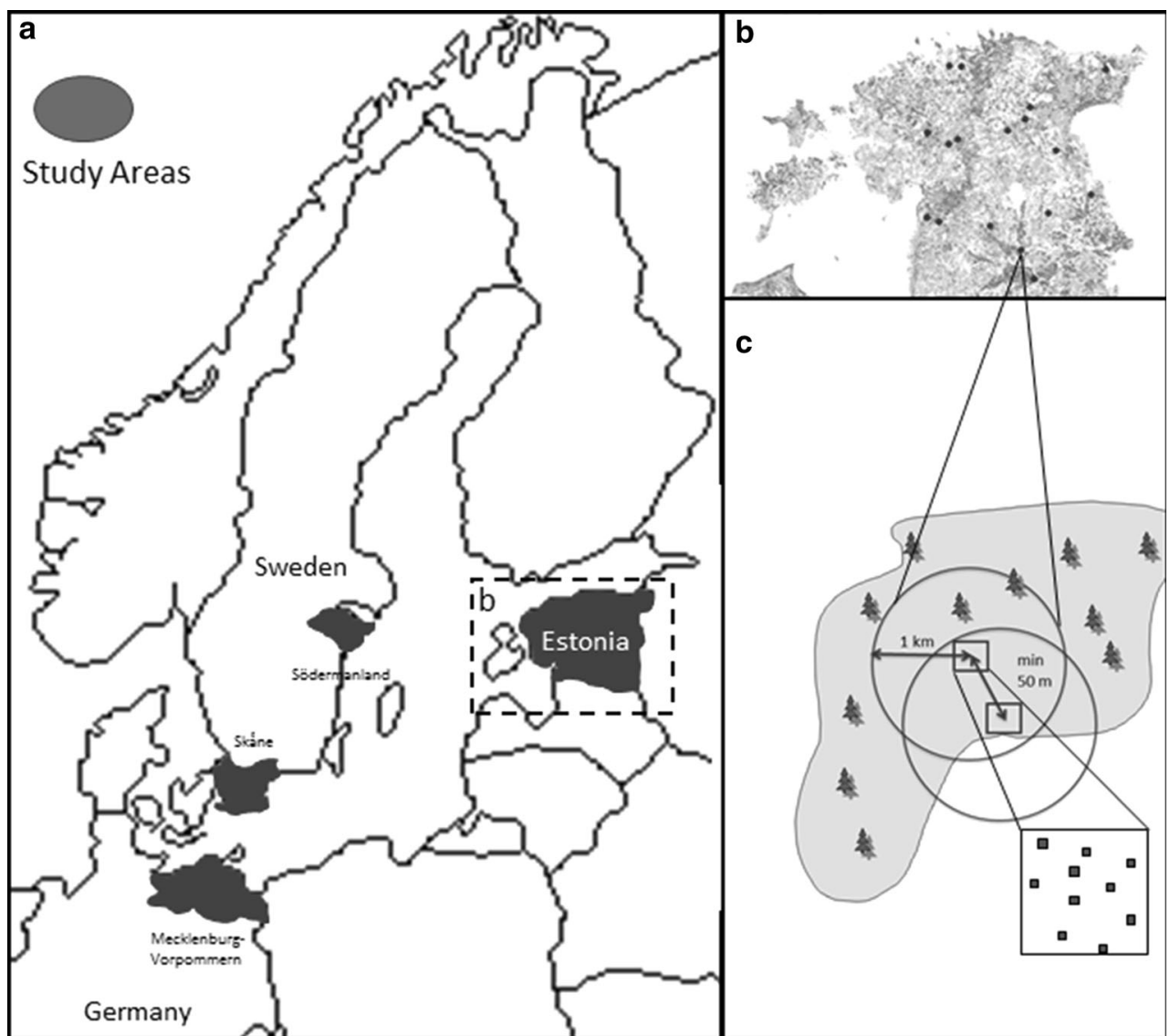

map. Starting from the top of the list, random coordinates in each region that were situated in a forest were chosen as study sites, excluding coordinates less than $2 \mathrm{~km}$ apart and coordinates situated on remote islands. Within each region, we randomly selected $27-31$ forested areas, in total 113 forest sites, which is assumed to be a representative selection of forest types in all four regions. At the chosen site, we established two $25 \mathrm{~m} \times 25 \mathrm{~m}\left(625 \mathrm{~m}^{2}\right)$ plots: one in the forest, called the core plot, at least $50 \mathrm{~m}$ from the nearest forest edge, and the second plot, called the edge plot, at the nearest forest edge from the core plot (Fig. 1c). The edge plot was always positioned at the nearest forest edge from the core plot, at a minimum of $50 \mathrm{~m}$ and maximum $1 \mathrm{~km}$ from the core plot, with one plot edge parallel to the forest edge. All forest edges in our study were easily identified due to a clear borderline between the forest with trees and the adjacent open habitat lacking tree stems, which could be a pasture, field, mire, a large roadside or other open habitat.

Our random sampling of forest sites generated a data set dominated by coniferous forests. The proportion of deciduous forest varied among regions. In Estonia and Germany, approximately $40 \%$ of the forests were deciduous. In Skåne $25 \%$ and in Södermanland, only $9 \%$ of the forests were deciduous. The proportion of forests with management restrictions in the form of nature reserves, nature parks, biotope protection, and landscape protection also varied among the four regions. $32 \%$ of the studied forests in Germany but only $10 \%$ in Estonia, $7 \%$ in Skåne, and $4 \%$ in Södermanland had some kind of management restrictions.

\section{Field inventories}

We carried out field inventories during all summer months (June to August) from June 2008 to August 2010 to measure the understory plant species richness in the forest sites. The sites were tracked in the landscape with the help of maps and a GPS hand unit. At a few sites, the forest had been recently cut. If there was forest left in the near surroundings, we randomly selected new coordinates within a radius of $1 \mathrm{~km}$. We established new coordinates using random numbers between 100 and $1000 \mathrm{~m}$ for distance and $0^{\circ}-360^{\circ}$ for direction. Otherwise, the site was rejected, and a new site was added from our list of random coordinates. In each large plot $(25 \times 25 \mathrm{~m})$, we distributed 10 small plots of $0.5 \times 0.5 \mathrm{~m}\left(0.25 \mathrm{~m}^{2}\right)$ using random numbers. In each small plot, we recorded the presence of all vascular plant species in the field layer (the layer of herbs and small shrubs), including seedlings of woody species. The 
reliability of the sampling design was checked using species accumulation curves. Estimated species diversity using a bootstrap method indicates that we found approximately $80 \%$ of all species in all regions (Online Resource 1). Therefore, we consider our recordings of species to be representative for the large plots and comparable across regions despite the fact that we missed a few species that lose all their above-ground parts after spring bloom. Specimens that we could not identify to species due to phenological stage or missing plant parts required for identification and species belonging to groups that are difficult to identify (e.g. some Hieracium and Taraxacum species), in total less than $2 \%$ out of all observations, were only identified to genus.

In addition to the species data, we measured light conditions and stem densities, recorded the stand type, and estimated the soil moisture in all forest sites studied. Light conditions were measured at each small plot by taking photographs of the forest canopy, with a camera positioned right above the plot, $50 \mathrm{~cm}$ above the forest floor aiming upwards. We used a Nikon D80 camera with a $28-\mathrm{mm}$ lens, exposure set to automatic. All images were converted to greyscale and analysed for the amount of free sky by thresholding in the GNU Image Manipulation Program (The GIMP Team 2010). We used the percentage of white pixels on photographs, representing openings in the canopy, as a measure of the amount of light penetrating the forest canopy and reaching the understory vegetation. Tree stem density was measured with a dendrometer (relascope) similar to the Bitterlich sampling technique (Bitterlich 1984). The stem density of trees was estimated in all large plots as the average of stem density measurements from three points within the large plots, located in three randomly selected small plots. We recorded all tree species of each large plot and noted the dominating tree species to determine the stand type. The following stand types were found: mixed coniferous ( $3 \%$ of the study plots), spruce (34\%), pine (25\%), mixed coniferous-deciduous (5\%), beech $(9 \%)$, and mixed deciduous (24\%). We estimated soil moisture based on instructions in the Swedish national forest survey (RIS 2008). At each small plot, we recorded the soil moisture as dry, mesic, mesicmoist, or moist (Markinfo 2006). The most common soil moisture category within each large plot was used as a combined measure at large plot level in the analyses.

\section{Landscape analysis}

To analyse the effect of forest area and forest edge length on species richness at a landscape scale, we established a circular zone with a radius of $1 \mathrm{~km}$ around each plot (Fig. 1). This circle size has been used in previous studies concerning landscape characteristics and distribution of plant populations (Rescia et al. 1995; Butaye et al. 2002).
The total forested area and the total forest edge length within each circle were measured by manually outlining forests from remote sensing data. For Sweden, we used satellite images dated from 2006 to 2007 in Google Earth (version 5.1., accessed 2009). In Estonia and Germany, we used satellite images from local Web Map Service through Geoportals (Federal State of Mecklenburg-Vorpommern 2009; Estonian Land Board 2012) in ArcMap (ESRI 2009). The pixel resolution of all images used was finer than $1 \mathrm{~m}$. We carried out tests with additional weighting of landscape characteristics according to distance to the study plot (Amici et al. 2015), but because they did not improve the analysis of landscape effects (Online Resource 2), the results presented in this paper were based on landscape characteristics estimated without distance weighting.

To evaluate the temporal continuity of studied forest sites, the presence of forest in studied plots was estimated from historical maps at two time points-in the beginning and in the middle of the twentieth century. If the study plot was continuously forested since the beginning of the twentieth century, the site was categorised as having long forest continuity. The forest site was considered to have long continuity also if it was managed as a production forest that goes through cycles of cutting and reforestation. Plots that were semi-natural grasslands or fields in the beginning of the twentieth century and were later afforested were considered as recently afforested sites. Sites with forest cover in the beginning of twentieth century that were converted to another land-use form, e.g. an arable field, pasture land, or meadow in the middle of the century, and later reforested were also considered as recently afforested. In 98 forest sites out of 113, the forest core and edge plots had the same continuity; in 12 cases, forest edge plots were recently established forests while the core plots had been forested continuously, and in 3 cases, the relationship was the opposite. Access to historical maps was gained through freely available sources. In Sweden, historical maps are available at www.lantmateriet.se (accessed November 2014-January 2015). These maps have a high resolution and accuracy (Jansson 1993). Information was extracted from cadastral maps (in Swedish Häradsekonomiska kartan) at a scale of 1:50,000 from 1897 to 1934 (hereafter 1900) and 1945 to 1974 (in Swedish Ekonomiska kartan) at a scale of 1:10,000. Web Map Services (WMS) were used in ArcMap applications (ESRI) in Estonia through Estonian Land Board homepage (http:// kaart.maaamet.ee/wms/ajalooline, accessed December 2014-January 2015) and in Germany through Mecklenburg-Vorpommern geoportal (http://www.gaia-mv.de/gaia/ gaia.php, accessed December 2014). Historical topographic maps from 1923 to 1935 at a scale of 1:25,000 (in Estonian Eesti Vabariigi topograafilised kaardid) and Soviet topographic maps (1942 reference system, in Estonian 
Nõukogude Liidu topograafilised kaardid) from 1935 to 1975 at a scale of 1:25,000 or 1:50,000 (in rare cases $1: 200,000)$ were available in Estonia. Historical topographic maps of Mecklenburg-Vorpommern from 1900s to 1980s at a scale of 1:25,000 (in German Messtischblatt TK25-M) were used in Germany.

\section{Habitat preferences of species}

To be able to test whether different types of species found in the forest respond differently to forest area and forest edge length in the landscape, we categorised all species found in our inventories to forest species and edge species (list of all species in Online Resource 3). Species that did not fit these two categories were not categorised. Forest species are species that have the interior of the forest as their primary habitat. Edge species are species found in the forest but near to or at the edge of the forest and the surrounding habitat. All the species that did not have forest or edge as their primary habitat were only included in the statistical analyses when testing total species richness. The categorisation of species was performed using literature from all four regions. Primarily, we used local floras from Germany (Oberdorfer 2001), Estonia (Kukk 1999), and Sweden (Hultén 1958) and habitat preference descriptions (Wulf 1997; Påhlsson 1998; Trass et al. 1999; Reier et al. 2005). We used earlier species lists in the literature to validate our classification (Brunet and von Oheimb 1998; Honnay et al. 1998; Hermy et al. 1999; Honnay et al. 1999; Dupre 2000; Graae 2000; Schmidt et al. 2002). Some of the species had different habitat preferences across regions. To create a common list of the forest and the edge species valid for the whole study area, regional habitat descriptions of the species were weighed together. A species was considered as a forest or edge species if it was listed as a forest or edge species, respectively, in at least three out of four regions.

To validate the accuracy of our categorisation, we tested whether ecological characteristics of the species groups differed, given the environmental conditions of the interior and the edge of a forest. Forest species are expected to be more tolerant to shady conditions and have larger seeds (Hodkinson et al. 1998) and a seed bank with shorter longevity (Bierzychudek 1982; Bossuyt and Hermy 2001) compared to edge species. Information on ecological characteristics of our plant species was found in the database of the Ecological Flora of The British Isles (Fitter and Peat 1994; Kleyer et al. 2008), the LEDA Traitbase (Kleyer et al. 2008), and Royal Botanic Gardens Kew Seed Information Database (SID) (Royal Botanic Gardens Kew 2014). In agreement with these databases, shade tolerance was measured according to Niinemets and Valladares (2006), Ellenberg's light index was from Ellenberg et al. (1991), and seed bank classification followed Thompson et al. (1997).

\section{Statistical analyses}

Species richness was estimated at two different spatial scales. Species richness in small plots was calculated as the mean species number of the ten small plots in each large plot (Fig. 1c). Species richness in large plots was calculated as the number of unique species in all ten small plots belonging to the same large plot. We used species accumulation curves to test that our assessed species richness values were reliable estimates of the true species richness of the study plots (Online Resource 1).

We carried out six different analyses to test the effect of landscape configuration on species richness: for species richness of all species $(n=307)$, the forest species $(n=75)$, and the edge species $(n=69)$ in both small and large plots. We used linear mixed-effects models using the function lme, implemented in the package nlme (Pinheiro et al. 2011) in R v. 2.15.1 ( $\mathrm{R}$ Development Core Team 2012) to account for the hierarchical structure of the sampling design. We carried out pilot tests where we tried to use ten different independent variables representing landscape configuration, local environmental conditions, and temporal forest continuity, but these models did not converge. Especially two of the covariates, soil moisture and stand type, were difficult to handle due to highly unbalanced number of plots in different regions despite trials to pool categories with few plots. Soil moisture and stand type were therefore excluded from the main analyses and tested separately to ensure that the variation among the study sites in these variables did not confound the analyses of landscape effects (Online Resource 4). The main analyses started with a full model with $\log$ (species number +1$)$ as a function of forest area $\left(\mathrm{km}^{2}\right)$, forest edge length $(\mathrm{km})$, study region, position of plot (core/edge), forest continuity, light condition, stem density, and site identity including all two- and three-way interactions. Site identity was included as a random factor to account for the paired design of core and edge plots. Continuous variables were centred before analysis. We used the stepAIC function of R package MASS (Venables and Ripley 2002) with Bayesian information criterion (BIC) as a penalty measure to test whether interactions should be included in the models. We found that the models only including main terms were the most informative and parsimonious for all analyses. We also found that the covariates forest continuity, light and stem density could be dropped from some of the models (Table 1). For the final model, we checked for the absence of multicollinearity among explanatory variables using correlations and variance inflation factors (VIF) in general linear models. We inspected that pairwise correlations among independent variables did not exceed 0.9 and that the VIF value of each effect was below 10.0 (Kutner et al. 2004). Normality of residuals was inspected 
from Q-Q plots of residuals and homogeneity of variance from plots of fitted values versus residuals. Spatial autocorrelation of residuals from all models was tested using Moran's I. Multiple comparisons were performed with Tukey's tests using the multcomp package (Hothorn et al. 2008).

\section{Results}

\section{Validation of study design and species characterisation}

As expected, the relationship between the two main landscape factors, forest area and the length of the forest edge, showed a humped-shaped pattern with the longest forest edge in landscapes with intermediate-sized forests (Fig. 2). We could see that different forest edge lengths and forest areas were evenly distributed among study sites, covering the whole range of the possible combinations of different areas and edge lengths. None of the models used for statistical analyses had residuals with spatial autocorrelation among sites (Moran's I, $p>0.05$ ).

To validate our species categorisation, we tested whether ecological characteristics of forest and edge species differed, given the environmental conditions of the interior and the edge of a forest. There was a significant difference in shade tolerance between the forest and edge species $\left(\chi^{2}=44.9811, \mathrm{df}=3, p<0.001\right) .54 \%$ of the forest species were tolerant to deep shade while only $10 \%$ of the species categorised as edge species could tolerate deep shade. Of the edge species, $61 \%$ tolerated only light shade and $29 \%$ were not shade-tolerant at all. Shade tolerance of the forest and edge species was also significantly different using Ellenberg's light index $\left(\chi^{2}=71.0767, d f=5\right.$, $p<0.001)$. The forest species were indicators of shade to semi-shade habitats (Ellenberg's light index 3, $8 \%$; 4, $32 \%$; and 5, $38 \%$ of the forest species). Only $4 \%$ of the species assigned as forest species had Ellenberg's light index value 7 , common for species in open habitats. Among the edge species in our study, $64 \%$ had Ellenberg's light index value 7 . According to seed bank longevity data, $22 \%$ of the edge species had a transient, $16 \%$ had a short-time persistent, and $54 \%$ had a long-time persistent seed bank. Of the forest species, $41 \%$ had a transient, $24 \%$ a short-time persistent and $26 \%$ a longtime persistent seed bank. Hence, the seed banks of edge species were significantly more long-lived than forest species $\left(\chi^{2}=9.8685, d f=3, p=0.020\right)$. Finally, as expected, the forest species in our species list had significantly heavier seeds than the edge species $(t=2.381$, $d f=120, p=0.019$, Student's $t$-test).

\section{Species richness of all understory vascular plants}

Species richness of all understory vascular plant species in small plots $\left(0.25 \mathrm{~m}^{2}\right)$ significantly increased with increasing forest area (Table 1; Fig. 3a). There was no significant effect of forest area on species richness in large plots $\left(625 \mathrm{~m}^{2}\right)$ (Table 1). Forest edge length had a significant positive effect on total species richness in both small and large plots (Table 1; Fig. 3b, c). Plant species richness decreased significantly with increasing stem density and was significantly higher in the edge plots than in the core plots (Table 1). There were significant differences in species richness among regions, but there were no significant interactions between region and landscape characteristics (Table 1; Online Resource 5, Fig. D2).

\section{Forest species}

Neither forest area nor the length of the forest edge had significant effects on species richness of the forest species in the small (Table 1; Fig. 4a) or in the large plots (Table 1; Fig. 4b). As expected, species richness of the forest species decreased significantly with increasing amount of light (Table 1). On the other hand, the forest species had higher species richness in the edge plots than in the core plots. Similarly as for all species, there were significant differences in species richness of the forest species among regions, but interactions between region and landscape characteristics were not significant (Table 1; Online Resource 5, Fig. D3a, b).

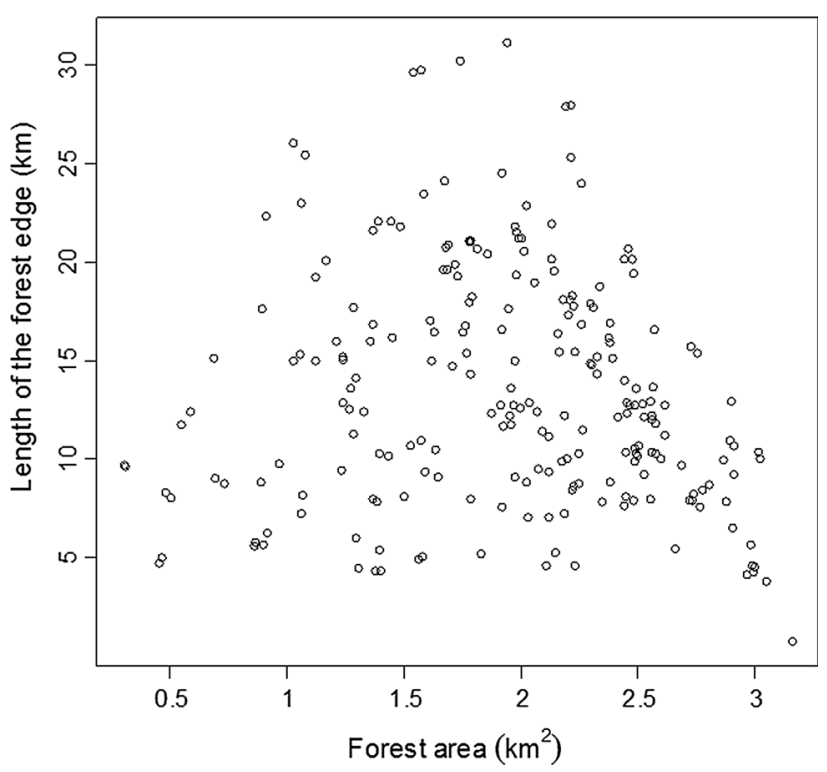

Fig. 2 Cumulative forest area $\left(\mathrm{km}^{2}\right)$ and forest edge length $(\mathrm{km})$ measured in circles with a $1-\mathrm{km}$ radius around all the study sites 
Table 1 Results of the linear mixed-effects models testing the effects of stem density, light, plot position in the forest (edge/core), region, forest area, and the length of the forest edge on the number of (a) all plant species, (b) forest plant species, and (c) edge plant species on large and small plot scale while controlling for the paired study design including forest identity as random variable

\begin{tabular}{|c|c|c|c|c|c|c|c|c|}
\hline \multirow[t]{2}{*}{ Variables } & \multicolumn{4}{|c|}{ Small plots } & \multicolumn{4}{|c|}{ Large plots } \\
\hline & Effect & df & $F$ & $p$ & Effect & df & $F$ & $p$ \\
\hline \multicolumn{9}{|l|}{ (a) All species } \\
\hline Stem density & - & 103 & 9.459 & 0.003 & - & 103 & 10.14 & 0.002 \\
\hline Edge/core & + & 103 & 7.639 & 0.007 & + & 103 & 11.85 & 0.001 \\
\hline Region & & 106 & 12.47 & $<0.001$ & & 106 & 9.880 & $<0.001$ \\
\hline Forest area & + & 103 & 5.232 & 0.024 & & 103 & 2.710 & 0.103 \\
\hline Edge length & + & 103 & 4.521 & $\mathbf{0 . 0 3 6}$ & + & 103 & 4.377 & $\mathbf{0 . 0 3 9}$ \\
\hline \multicolumn{9}{|l|}{ (b) Forest species } \\
\hline Light & - & 103 & 10.77 & 0.001 & - & 103 & 18.86 & $<\mathbf{0 . 0 0 1}$ \\
\hline Edge/core & $(+)$ & 103 & 3.112 & 0.081 & + & 103 & 5.767 & 0.018 \\
\hline Region & & 106 & 11.84 & $<0.001$ & & 106 & 17.60 & $<\mathbf{0 . 0 0 1}$ \\
\hline Forest area & & 103 & 2.465 & 0.120 & & 103 & 2.695 & 0.104 \\
\hline Edge length & & 103 & 1.612 & 0.207 & & 103 & 1.341 & 0.250 \\
\hline \multicolumn{9}{|l|}{ (c) Edge species } \\
\hline Stem density & - & 102 & 9.683 & 0.002 & - & 102 & 13.25 & $<0.001$ \\
\hline Edge/core & + & 102 & 10.40 & 0.002 & + & 102 & 14.15 & $<\mathbf{0 . 0 0 1}$ \\
\hline Region & & 106 & 5.752 & 0.001 & & 106 & 3.247 & 0.025 \\
\hline Forest continuity & - & 102 & 5.673 & 0.019 & - & 102 & 5.795 & 0.018 \\
\hline Forest area & $(+)$ & 103 & 2.808 & 0.097 & & 102 & 1.408 & 0.238 \\
\hline Edge length & + & 102 & 5.974 & 0.016 & $(+)$ & 102 & 4.523 & 0.056 \\
\hline
\end{tabular}

The direction of the slope of regression lines $(+$ or - ) for each significant numeric effect is given in the column Effect. Marginally significant effects are in parentheses. A + sign for the variable edge/core indicates a positive effect of edge plots compared to core plots. A - sign for the variable forest continuity indicates a negative effect of forest continuity on species richness. Significant $p$ values are shown in bold (a)

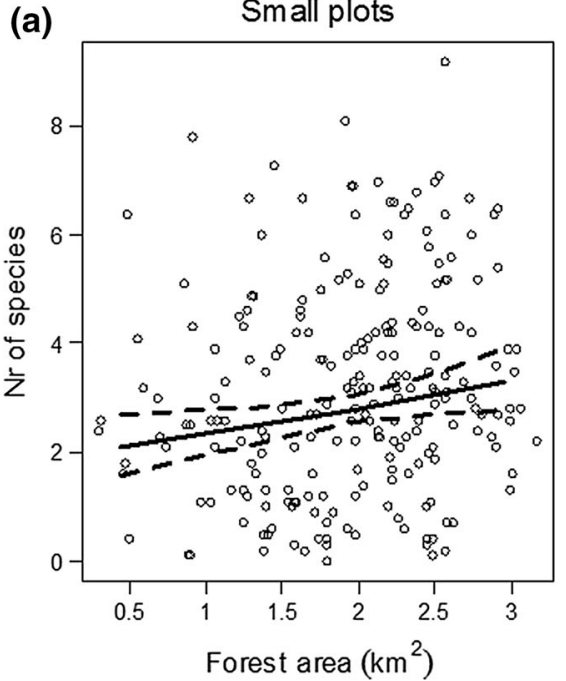

(b)

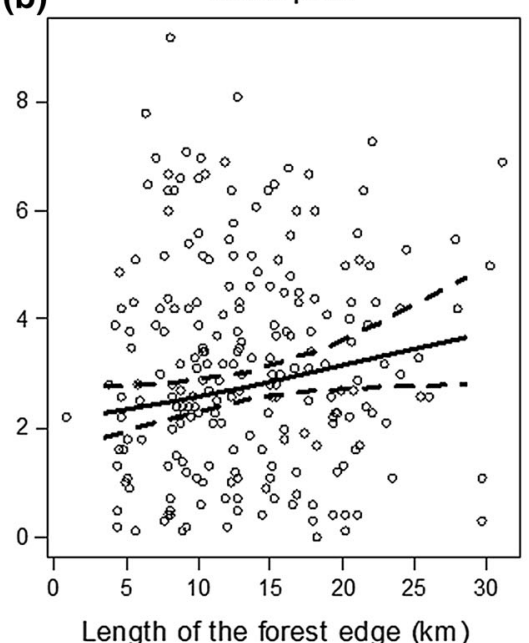

(c)

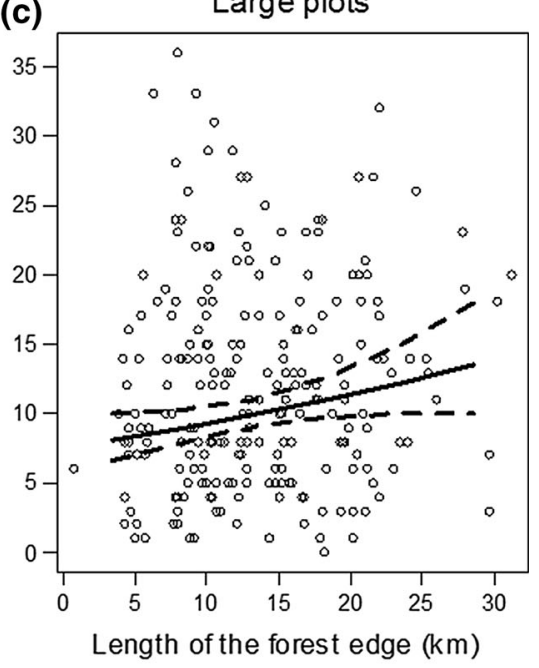

Fig. 3 Effect of a forest area on total species number of all understory plant species in small plots, $\mathbf{b}$ effect of length of forest edge in small and c large plots with $95 \%$ confidence bands (dashed lines) calculated from linear mixed-effects model

\section{Edge species}

Species richness of the edge species increased significantly in small plots when the length of the forest edge in the adjacent landscape increased and the increase was marginally significant in large plots (Table 1 ; Fig. 4c, d). Forest area had a marginally significant positive effect in small plots and no effect in large plots on species richness of the edge species (Table 1). Species richness of the edge species was significantly lower in plots that had been 
Fig. 4 Relationship between forest area and species richness of forest plant species in a small and $\mathbf{b}$ large plots (linear mixedeffects model, n.s. in both cases) and effect of length of forest edge on species richness of edge plant species in c small and d large plots with $95 \%$ confidence bands (dashed lines) calculated from linear mixedeffects model
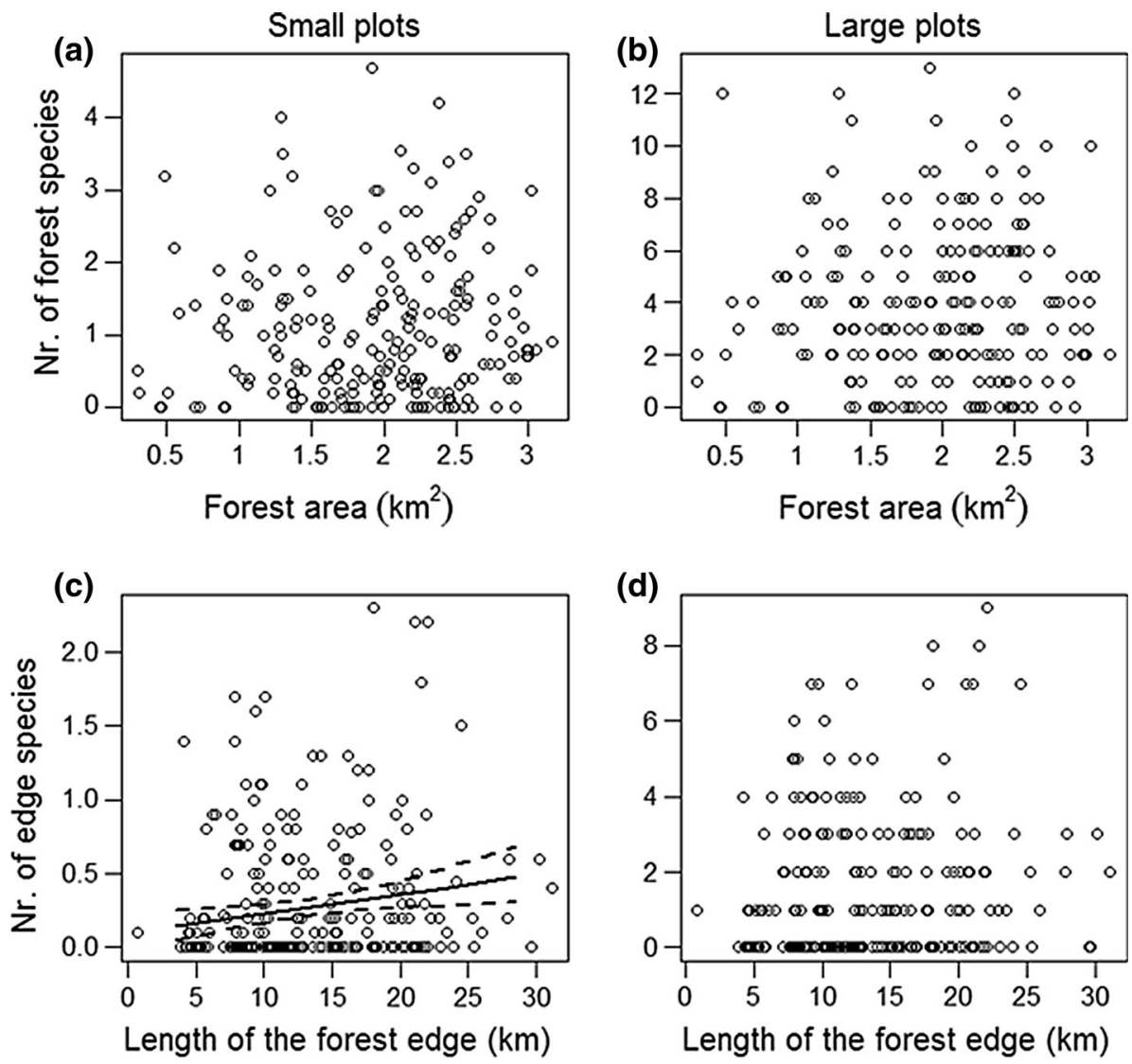

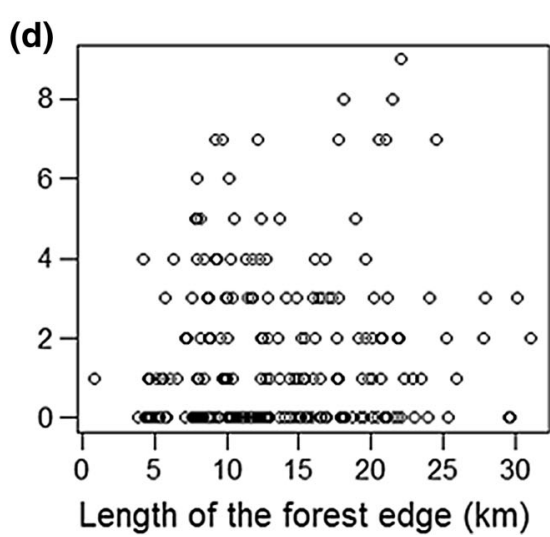

continuously forested during the last century (Table 1). There was a significant negative effect of stem density on species richness of the edge species (Table 1). As expected, species richness of the edge species was significantly higher in the edge plots than in the core plots (Table 1). There were significant differences in species richness among regions, but also here there were no significant interactions between region and landscape characteristics (Table 1; Online Resource 5, Fig. D3c, d).

\section{Discussion}

\section{Landscape effect on local species richness}

There was a positive effect of forest area on local species richness of vascular plants when controlling for the length of the forest edge in the models. To our knowledge, the empirical studies on the relationship between habitat area in a landscape and local plant species richness are still scarce (but see Petit et al. 2004; Redon et al. 2014). Paltto et al. (2006) showed that the richness of red-listed species of vascular plants, lichens, bryophytes, and fungi was positively correlated with the proportion of suitable habitat in the landscape, while indicator species, i.e. species used to locate 'hot spots' of forest diversity, were unaffected.
High total species richness can be maintained locally through spatial mass effects (Shmida and Whittaker 1981; Shmida and Ellner 1984); with increasing forest area in the landscape, forest habitats in the surroundings can serve as source populations. Due to the rescue effect, populations of species experiencing suboptimal conditions with low fitness and survival rates may be supported by immigration (Zeleny et al. 2010). In this manner, more species can coexist locally. As formulated in the landscape species pool hypothesis (Tscharntke et al. 2012), large habitats may thereby support larger populations reducing the likelihood of stochastic extinctions. Interestingly, the effect of forest area was significant at our smallest plot scale $\left(0.25 \mathrm{~m}^{2}\right)$ but not at large plot scale $\left(625 \mathrm{~m}^{2}\right)$. A possible explanation is that large plots become filled with most species of the regional species pool even in landscapes with low forest area, whereas small plots are affected by a discernible spatial mass effect because they represent a smaller sample of the species pool. Many of the forest sites of this study are young production forests in highly managed landscapes that have a species pool with a limited number of species with fairly similar abundance. This is a prerequisite for saturation of species richness that seemed to occur at large plot scale. It is also noticeable that the pattern detected in these rather species-poor forests is opposite to the results from similar studies in more species-rich grasslands. 
Reitalu et al. (2012) found a positive habitat area effect on species richness on a large plot scale (0.1-4.8 ha polygons), but there was no significant area effect on species richness at a small plot scale $\left(0.25 \mathrm{~m}^{2}\right)$. This was true both for grassland specialist species and for generalist species.

Furthermore, our study revealed that local species richness of all vascular plants of the understory, in both small and large plots, increased significantly with increasing forest edge length in the landscape. Increased forest edge length did not seem to have a negative effect on local species richness through reduced patch size or increased dispersal barriers. This finding is consistent with the idea that forest edge can be regarded as a distinct habitat type. Longer forest edge means that the amount of edge habitat in the landscape increases (Hofmeister et al. 2013). Applying the landscape species pool hypothesis (Tscharntke et al. 2012), the regional species pool of this habitat type then becomes larger which has a positive effect on local species richness. The length of the forest edge was positively related to species richness in both the edge plots and the forest core plots, since there was no significant interaction between the length of the forest edge and the position of a plot in a forest. Thus, the results suggest that the spatial mass effect detected at edge habitat in the landscape affects plant communities in the whole forest, both at the forest edges and in the forest interior.

As expected, some regional differences were found. Total species richness was significantly higher in Estonia and Södermanland compared to Skåne and northern Germany. However, since there were no interactions between region and landscape characteristics, the effects of forest area and the length of the forest edge on species richness were the same in all four regions. There was neither any interaction between temporal continuity of the forest in our study plots and landscape characteristics meaning that the relationship between landscape characteristics and local species richness was similar in recently afforested and continuously forested sites.

Our study is based on a randomised sampling design, where ten small plots of $0.25 \mathrm{~m}^{2}$ were used to estimate the species richness in the large plots of $625 \mathrm{~m}^{2}$. We tested the efficiency of the sampling design with species accumulation curves (Online Resource 1). The accumulation curves of all species flattened out and they seldom crossed. We found approximately $80 \%$ of all species. Therefore, we conclude that the sampling design is sufficient for the purposes of our analyses, even if the sampling was not exhaustive.

\section{Forest and edge species}

Species can respond differently to habitat patterns in their near surroundings and at varying spatial and temporal scales due to species-specific traits related to persistence, dispersal, and recruitment (Wiens 1989; Verheyen et al. 2003; Petit et al. 2004; Lindborg et al. 2012). In this study, we found that the forest species and the edge species responded differently to landscape configuration. Local species richness of the forest species was dependent neither on forest area nor on forest edge length in the landscape. Habitat quantity at the landscape scale was perhaps not a limiting factor for the forest species at the scale of our sampling design. It is also possible that local populations of the forest species are stable and have high viability and therefore do not respond to the amount of surrounding habitat. According to Levins model (Levins 1969, 1970), a metapopulation can persist when the colonisation rate exceeds the extinction rate. Extinction probability is low for long-lived forest species (Jacquemyn et al. 2006), and colonisation events should therefore not be especially important for metapopulation persistence of forest species. Consequently, the landscape effect on species richness of forest species is not easily detectable even with rather large data sets such as in this study (113 sites). The long lifespans of many forest plants create high inertia of forest plant communities, suggesting that there is a need to further explore historical landscape patterns and include temporal lag effects for spatial processes governing local species richness of the forest species (Bierzychudek 1982; Inghe and Tamm 1985; Cain and Damman 1997; Ehrlén and van Groenendael 1998; Ehrlén and Lehtilä 2002). We did not find any effect of temporal forest continuity on species richness of forest species in our study plots. Even though it could be expected that species richness of forest plants is higher in forests with long temporal continuity (Flinn and Vellend 2005; Honnay et al. 2005), production forests may not show this pattern, at least not in a time frame of 100 years (Vellend et al. 2006; Kolk and Naaf 2015). In this study, local species richness of the forest species was low even in the forests with long continuity.

Although the species of our forest species list had typical ecological characteristics of forest plants, surprisingly, we found that the edge plots had a higher species richness of forest species than the forest interior plots. Other studies have found that distance from the edge has a positive effect on species richness of forest specialists (Hofmeister et al. 2013; Pellissier et al. 2013; but see Vockenhuber et al. 2011). In these studies, it was found that the edge effect reached to distances of up to $200-800 \mathrm{~m}$, suggesting that some of our forest interior plots could still be affected by edge conditions. However, possible edge influence in our forest interior plots does not explain why the forest species were more numerous in the edge plots in our study. The pattern may be due to a high proportion of production forests in our data. Production forests are managed as evenaged monocultures often detrimental to biodiversity (Brockerhoff et al. 2008), where management can be more 
intense in the forest interior (Angelstam and Pettersson 1997). Environmental conditions for plants, even for forest species, may therefore be better at the forest edge.

Species richness of the edge species was positively affected by the length of the forest edge in the adjacent landscape in small plots, and the effect was marginally significant in large plots. More forest edge in the landscape provides more suitable habitat for the edge species to colonise and to persist in. Edge species are usually described as light-demanding, good dispersers and fast colonisers due to large production of many small seeds (Lindborg et al. 2012) and can therefore rapidly colonise empty habitat patches. We found that species richness of the edge species was higher in recently afforested sites. These recent forests may have abiotic conditions favouring edge species. The composition of the current plant community is also affected by the legacy of former vegetation types (Flinn and Vellend 2005; Jonason et al. 2014). The positive effect of forest edge length on species richness of edge species suggests that the regional species pool of the edge ecotone, at least partly, is different from the species pool of the forest interior. However, there was also a positive edge length effect on species richness in the analysis with all understory species. Forest edge length may therefore be an indicator of landscape matrix heterogeneity that can increase the regional species pool of generalist species that are also able to colonise forests. High landscape matrix heterogeneity could, on the other hand, cause a negative fragmentation effect (Zeleny et al. 2010), but such a negative effect was not observed either for total plant species richness or for species richness of plants of the forest interior or of the edge.

\section{Conclusions}

Our study showed that total species richness of vascular plant communities of forests was affected by the configuration of the surrounding forest landscape. The landscape effect was not evident for plant species that have the forest interior as their primary habitat. The life history traits of these forest species may render them to be insensitive or respond slowly to landscape effects. On the other hand, species richness of the edge species was significantly higher in plots with recent forest than in plots with forest of long continuity. The edge species showed positive association with the length of the forest edge, which can be explained by the spatial mass effect (Shmida and Whittaker 1981). The spatial mass effect is usually viewed as a process-dependent on habitat area and not on perimeter length. In our case, the forest edge length was an indicator of the size of edge habitat (Murcia 1995; Ries et al. 2004; Ewers and Didham 2006; Marchand and Houle 2006).
Our results suggest that forest edge length had a stronger landscape effect on understory plant species richness than forest area, and that the effect was strongest for edge species and total species richness. Implications of these findings for the management of forest landscapes depend on priorities given to different species groups in biodiversity conservation, i.e. if emphasis is in total species richness or species richness of forest or edge species. It is important to remember that these results are based on randomly sampled forested areas in northern Europe, where production forests with relatively low species diversity are the most common element of forest landscapes. Obviously, understory flora of specific, highly valued forest types, e.g. old-growth forests, may well exhibit other types of responses to landscape configuration. On the other hand, production forests are especially important for biodiversity management in regions with few reserves and for future preservation of species diversity due to their commonness. Understanding the mechanisms acting on different spatial and temporal scales creating diversity patterns will help us to make well-substantiated decisions about management regimes and biodiversity conservation.

Acknowledgments We would like to thank The Foundation for Baltic and East European Studies for financing this work. Field work was carried out with the great help from Anne-Charlotte Hansson, Sofia Lilja nee Eriksson, Merit Mägi, Marge Mägi, Helena Mägi, and Kaupo Kütt. We are grateful for all the help with GIS to Christopher Zetterberg, and we would like to thank anonymous reviewers for their valuable comments.

Open Access This article is distributed under the terms of the Creative Commons Attribution 4.0 International License (http://crea tivecommons.org/licenses/by/4.0/), which permits unrestricted use, distribution, and reproduction in any medium, provided you give appropriate credit to the original author(s) and the source, provide a link to the Creative Commons license, and indicate if changes were made.

\section{References}

Amici V, Rocchini G, Filibeck G, Bacaro G, Santi E, Geri F, Landi S, Scoppola A, Chiarucci A (2015) Landscape structure effects on forest plant diversity at local scale: exploring the role of spatial extent. Ecol Complex 21:44-52

Angelstam P, Pettersson B (1997) Principles of present Swedish forest biodiversity management. Ecol Bull 46:191-203

Bierzychudek P (1982) Life histories and demography of shadetolerant temperate forest herbs: a review. New Phytol 90:757-776

Bitterlich W (1984) The relascope idea. Relative measurements in forestry. Commonwealth Agricultural Bureau, Slough

Bossuyt B, Hermy M (2001) Influence of land use history on seed banks in European temperate forest ecosystems: a review. Ecography 24:225-238

Brockerhoff EG, Shaw WB, Hock B, Kimberley M, Paul T, Quinn J, Pawson S (2008) Re-examination of recent loss of indigenous 
cover in New Zealand and the relative contributions of different land uses. N Z J Ecol 32:115-126

Brothers TS, Spingarn A (1992) Forest fragmentation and alien plant invasion of central Indiana old-growth forests. Conserv Biol 6:91-100

Brunet J, von Oheimb G (1998) Migration of vascular plants to secondary woodlands in southern Sweden. J Ecol 86:429-438

Butaye J, Jacquemyn H, Honnay O, Hermy M (2002) The species pool concept applied to forests in a fragmented landscape: dispersal limitation versus habitat limitation. J Veg Sci 13:27-34

Cain ML, Damman H (1997) Clonal growth and ramet performance in the woodland herb, Asarum canadense. J Ecol 85:883-897

Christiansen L (2014) Skogsstatistisk årsbok 2014. Skogsstyrelsen

Cousins SAO, Auffret AG, Lindgren J, Trank L (2015) Regionalscale land-cover change during the 20th century and its consequences for biodiversity. Ambio 44:17-27

Dengler J (2009) Which function describes the species-area relationship best? A review and empirical evaluation. J Biogeogr 36:728-744

Dupre C (2000) How to determine a regional species pool: a study in two Swedish regions. Oikos 89:128-136

Ehrlén J, Lehtilä K (2002) How perennial are perennial plants? Oikos 98:308-322

Ehrlén J, van Groenendael JM (1998) The trade-off between dispersability and longevity - an important aspect of plant species diversity. Appl Veg Sci 1:29-36

Ellenberg H, Weber HE, Düll R, Wirth V, Werner W, Paulißen D (1991) Zeigerwerte von Pflanzen in Mitteleuropa. Scripta Geobotanica 18, Goltze Verlag, Göttingen

ESRI (2009) ArcEditor 9.2.1 and extensions. ESRI, Redlands

Esseen P-A, Ehnström B, Ericson L, Sjöberg K (1997) Boreal forests. Ecol Bull 46:16-47

Estonian Land Board (2012) Geoportal. www.geoportaal.maaamet.ee, Tallinn, Estonia. www.geoportaal.maaamet.ee. Accessed Jan 2012, Dec 2014 to Jan 2015

Ewers RM, Didham RK (2006) Confounding factors in the detection of species responses to habitat fragmentation. Biol Rev $81: 117-142$

Fagan WE, Cantrell RS, Cosner C (1999) How habitat edges change species interactions. Am Nat 153:165-182

Fahrig L (2003) Effects of habitat fragmentation on biodiversity. Ann Rev Ecol Evol Syst 34:487-515

Federal State of Mecklenburg-Vorpommern (2009) GeoPortal. MV. Schwerin, Germany. www.geoportal-mv.de. Accessed 2009 and Dec 2014

Fischer J, Lindenmayer DB (2007) Landscape modification and habitat fragmentation: a synthesis. Glob Ecol Biogeogr $16: 265-280$

Fitter AH, Peat HJ (1994) The ecological flora database. J Ecol $82: 415-425$

Fletcher RJ, Jr, Ries L, Battin J, Chalfoun AD (2007) The role of habitat area and edge in fragmented landscapes: definitively distinct or inevitably intertwined? Can J Zool 85:1017-1030

Flinn KM, Vellend M (2005) Recovery of forest plant communities in post-agricultural landscapes. Front Ecol Environ 3:243-250

Fox BJ, Taylor JE, Fox MD, Williams C (1997) Vegetation changes across edges of rainforest remnants. Biol Conserv 82:1-13

Fraver S (1994) Vegetation responses along edge-to-interior gradients in the mixed hardwood forests of the Roanoke river basin, NorthCarolina. Conserv Biol 8:822-832

Godefroid S, Koedam N (2003) How important are large vs. small forest remnants for the conservation of the woodland flora in an urban context? Glob Ecol Biogeogr 12:287-298

Graae BJ (2000) The effect of landscape fragmentation and forest continuity on forest floor species in two regions of Denmark. J Veg Sci 11:881-892
Hanski I (1999) Metapopulation ecology. Oxford University Press, Oxford

Hermy M, Honnay O, Firbank L, Grashof-Bokdam C, Lawesson JE (1999) An ecological comparison between ancient and other forest plant species of Europe, and the implications for forest conservation. Biol Conserv 91:9-22

Hodkinson DJ, Askew AP, Thompson K, Hodgson JG, Bakker JP, Bekker RM (1998) Ecological correlates of seed size in the British flora. Funct Ecol 12:762-766

Hofmeister J, Hosek J, Brabec M, Hedl R, Modry M (2013) Strong influence of long-distance edge effect on herb-layer vegetation in forest fragments in an agricultural landscape. Perspect Plant Ecol 15:293-303

Holt RD (2010) Toward a trophic island biogeography: reflections on the interface of island biogeography and food web ecology. In: Losos JB, Ricklefs RE (eds) The theory of island biogeography revisited. Princeton University Press, Princeton, pp 143-185

Honnay O, Degroote B, Hermy M (1998) Ancient-forest plant species in Western Belgium: a species list and possible ecological mechanisms. Belg J Bot 130:139-154

Honnay O, Hermy M, Coppin P (1999) Impact of habitat quality on forest plant species colonization. For Ecol Manag 115:157-170

Honnay O, Bossuyt B, Verheyen K, Butaye J, Jacquemyn H, Hermy M (2002a) Ecological perspectives for the restoration of plant communities in European temperate forests. Biol Conserv $11: 213-242$

Honnay O, Verheyen K, Hermy M (2002b) Permeability of ancient forest edges for weedy plant species invasion. For Ecol Manag 161:109-122

Honnay O, Jacquemyn H, Bossuyt B, Hermy M (2005) Forest fragmentation effects on patch occupancy and population viability of herbaceous plant species. New Phytol 166:723-736

Hothorn T, Bretz F, Westfall P (2008) Simultaneous inference in general parametric models. Biom J 50:346-363

Hultén E (1958) Vår svenska flora i färg. Esselte AB, Stockholm

Inghe O, Tamm CO (1985) Survival and flowering of perennial herbs. 4. The behaviour of Hepatica nobilis and Sanicula europaea on permanent plots during 1943-1981. Oikos 45:400-420

Jacquemyn H, Brys R, Honnay O, Hermy M, Roldan-Ruiz I (2006) Sexual reproduction, clonal diversity and genetic differentiation in patchily distributed populations of the temperate forest herb Paris quadrifolia (Trilliaceae). Oecologia 147:434-444

Jamoneau A, Chabrerie O, Closset-Kopp D, Decocq G (2012) Fragmentation alters beta-diversity patterns of habitat specialists within forest metacommunities. Ecography 35:124-133

Jansson U (1993) Ekonomiska kartor. 1800-1934. En studie av småskaliga kartor med information om markanvändning. Riksantikvarieämbetet, Stockholm

Jonason D, Ibbe M, Milberg P, Tuner A, Westerberg L, Bergman KO (2014) Vegetation in clear-cuts depends on previous land use: a century-old grassland legacy. Ecol Evol 4:4287-4295

Kleyer M, Bekker RM, Knevel IC et al (2008) The LEDA Traitbase: a database of life-history traits of the Northwest European flora. J Ecol 96:1266-1274

Kolk J, Naaf T (2015) Herb layer extinction debt in highly fragmented temperate forests-completely paid after 160 years? Biol Conserv 182:164-172

Kukk T (1999) Eesti taimestik. Teaduste Akadeemia Kirjastus, Tartu

Kutner M, Nachtsheim C, Neter J (2004) Applied linear regression models. McGraw-Hill-Irwin, New york

Laurance WF, Nascimento HEM, Laurance SG, Andrade AC, Fearnside PM, Ribeiro JEL, Capretz RL (2006) Rain forest fragmentation and the proliferation of successional trees. Ecology $87: 469-482$

Leibold MA, Holyoak M, Mouquet N, Amarasekare P, Chase JM, Hoopes MF, Holt RD, Shurin JB, Law R, Tilman D, Loreau M, 
Gonzalez A (2004) The metacommunity concept: a framework for multi-scale community ecology. Ecol Lett 7:601-613

Levins R (1969) Some demographic and genetic consequences of environmental heterogeneity for biological control. Bull Entomol Soc Am 15:237-240

Levins R (1970) Extinction. Lect Notes Math 2:75-107

Lindborg R, Helm A, Bommarco R, Heikkinen RK, Kuhn I, Pykala J, Pärtel M (2012) Effect of habitat area and isolation on plant trait distribution in European forests and grasslands. Ecography 35:356-363

Lomolino MV (2000) Ecology's most general, yet protean pattern: the species-area relationship. J Biogeogr 27:17-26

MacArthur RH, Wilson EO (1967) The theory of island biogeography. Princeton University Press, Princeton

Marchand P, Houle G (2006) Spatial patterns of plant species richness along a forest edge: what are their determinants? For Ecol Manag 223:113-124

Markinfo (2006) Soil moisture: definition. http://www-markinfo.slu. se/eng/soildes/fukt/skfukt1.html

Matthews TJ, Cottee-Jones HE, Whittaker RJ (2014) Habitat fragmentation and the species-area relationship: a focus on total species richness obscures the impact of habitat loss on habitat specialists. Divers Distrib 20:1136-1146

Murcia C (1995) Edge effects in fragmented forests: implications for conservation. Trends Ecol Evol 10:58-62

Niinemets Ü, Valladares F (2006) Tolerance to shade, drought, and waterlogging of temperate Northern Hemisphere trees and shrubs. Ecol Monogr 76:521-547

Oberdorfer E (2001) Pflanzen-soziologische Exkursions-flora für Deutschland und angrenzende Gebiete. Eugen Ulmer GmbH \& Co., Stuttgart

Ouborg NJ, Eriksson O (2004) Toward a metapopulation concept for plants. In: Hanski I, Gaggiotti OE (eds) Ecology, genetics and evolution of metapopulations. Elsevier, London, pp 447-469

Ovaskainen O, Hanski I (2004) Metapopulation dynamics in highly fragmented landscapes. In: Hanski I, Gaggiotti OE (eds) Ecology, genetics and evolution of metapopulations. Elsevier, London, pp 73-103

Påhlsson L (1998) Vegetationstyper i Norden. Nordisk Ministerråd, Kobenhavn

Paltto H, Norden B, Gotmark F, Franc N (2006) At which spatial and temporal scales does landscape context affect local density of Red Data Book and Indicator species? Biol Conserv 133:442-454

Pellissier V, Bergès L, Nedeltcheva T, Schmitt MC, Avon C, Cluzeau C, Dupouey JL (2013) Understorey plant species show longrange spatial patterns in forest patches according to distance-toedge. J Veg Sci 24:9-24

Peterken GF (1996) Natural woodland: ecology and conservation in northern temperate regions. Cambridge University Press, Cambridge

Petit S, Griffiths L, Smart SS, Smith GM, Stuart RC, Wright SM (2004) Effects of area and isolation of woodland patches on herbaceous plant species richness across Great Britain. Landsc Ecol 19:463-471

Pinheiro J, Bates D, DebRoy S, Sarkar D, Team RC (2011) nlme: linear and nonlinear mixed effects models. $\mathrm{R}$ package 2.15 .1

Põder K (2014) Eesti statistiska aastaraamat 2014. Statistikaamet

R Development Core Team (2012) R: a language and environment for statistical computing. R Foundation for Statistical Computing, Vienna

Redon M, Berges L, Cordonnier T, Luque S (2014) Effects of increasing landscape heterogeneity on local plant species richness: how much is enough? Landsc Ecol 29:773-787

Reier U, Tuvi EL, Pärtel M, Kalamees R, Zobel M (2005) Threatened herbaceous species dependent on moderate forest disturbances: a neglected target for ecosystem-based silviculture. Scand J For Res 20:145-152

Reitalu T, Purschke O, Johansson LJ, Hall K, Sykes MT, Prentice HC (2012) Responses of grassland species richness to local and landscape factors depend on spatial scale and habitat specialization. J Veg Sci 23:41-51

Rescia AJ, Schmitz MF, Deagar MPM, Depablo CL, Pineda FD (1995) Ascribing plant diversity values to historical changes in landscape: a methodological approach. Landsc Urban Plan 31:181-194

Ries L, Fletcher RJ, Battin J, Sisk TD (2004) Ecological responses to habitat edges: mechanisms, models, and variability explained. Annu Rev Ecol Evol Syst 35:491-522

RIS (2008) Riksinventering av skog. www.slu.se/globalassets/ny_ struktur/org/centrb/rt/dokument/faltinst/ris_fin_2005.pdf. Accessed 2008

Royal Botanic Gardens Kew (2014) Seed Information Database (SID). http://data.kew.org/sid/. Accessed 2014

Schmidt M, von Oheimb G, Kriebitzsch WU, Ellenberg H (2002) Liste der im norddeutschen Tiefland typischen Waldgefäbpflanzen. Kommisionsverlag, Hamburg

Shmida A, Ellner S (1984) Coexistence of plant-species with similar niches. Vegetatio 58:29-55

Shmida A, Whittaker RH (1981) Pattern and biological microsite effects in two shrub communities, southern California. Ecology 62:234-251

The GIMP Team (2010) The GIMP (GNU Image Manipulation Program). www.gimp.org2010. Accessed 2010

Thompson K, Bakker JP, Bekker RM (1997) The soil seed banks of North West Europe: methodology, density and longevity. Cambridge University Press, Cambridge

Thünen-Institut (2015) Dritte Bundeswaldinventur. Ergebnisdatenbank. http://bwi.info. Accessed 2015

Tilman D (2004) Niche tradeoffs, neutrality, and community structure: a stochastic theory of resource competition, invasion, and community assembly. Proc Natl Acad Sci USA 101:10854-10861

Trass H, Vellak K, Ingerpuu N (1999) Floristical and ecological properties for identifying of primeval forests in Estonia. Ann Bot Fenn 36:67-80

Tscharntke T, Tylianakis JM, Rand TA et al (2012) Landscape moderation of biodiversity patterns and processes-eight hypotheses. Biol Rev 87:661-685

Vellend M, Verheyen K, Jacquemyn H, Kolb A, Van Calster H, Peterken G, Hermy M (2006) Extinction debt of forest plants persists for more than a century following habitat fragmentation. Ecology 87:542-548

Venables WN, Ripley BD (2002) Modern applied statistics with S. Springer, New York

Verheyen K, Bossuyt B, Honnay O, Hermy M (2003) Herbaceous plant community structure of ancient and recent forests in two contrasting forest types. Basic Appl Ecol 4:537-546

Vockenhuber EA, Scherber C, Langenbruch C, Meißner M, Seidel D, Tscharntke T (2011) Tree diversity and environmental context predict herb species richness and cover in Germany's largest connected deciduous forest. Perspect Plant Ecol 13:111-119

Wiens JA (1989) Spatial scaling in ecology. Funct Ecol 3:385-397

With KA, King AW (1999) Extinction thresholds for species in fractal landscapes. Conserv Biol 13:314-326

Wulf M (1997) Plant species as indicators of ancient woodland in northwestern Germany. J Veg Sci 8:635-642

Zeleny D, Li CF, Chytry M (2010) Pattern of local plant species richness along a gradient of landscape topographical heterogeneity: result of spatial mass effect or environmental shift? Ecography 33:578-589 